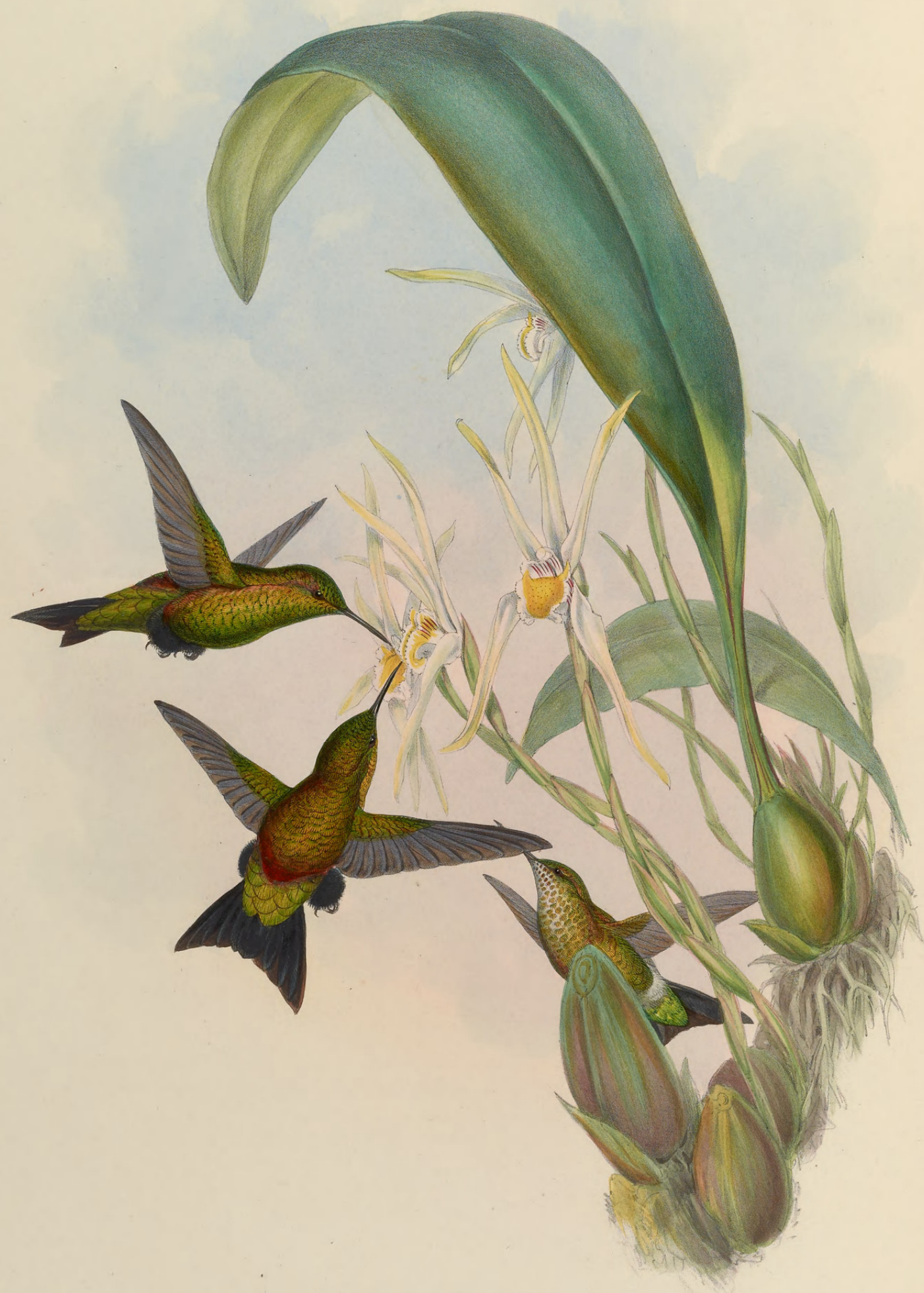




\title{
ERIOCNEMIS DERBIANUS.
}

\author{
Derby's Puff-leg.
}

Trochilus Derbyi, De Latt. et Bourc. Rev. Zool. 1846, p. 306.

Eriopus Derbyi, Gould in Proc. of Zool. Soc., part xv. p. 17.

- derbyi, Bonap. Consp. Gen. Av., p. 80, Eriopus, sp. 7.

Eriocnemys derbyanus, Bonap. Rev. et Mag. de Zool. 1854, p. 252.

Threptia Derbyi, Reichenb. Aufz. der Colibris, p. 9.

Tнат the study of the great family of the Trochilidæ, when all the species are known and the areas of habitat enjoyed by each are ascertained, will tend to throw some light on what may or may not be termed species, I think there can be little doubt. The various members of the genera Oreotrochilus, Oxypogon and Ramphomicron live at elevations varying from 10,000 to 16,000 feet, and are confined to such limited areas, that a single cone like that of Chimborazo or Cotopaxi is the extent of their range; on the other hand, many of the extinct volcanos have species peculiar to the shrubby regions on their inner sides. Surely such facts as these are worthy of a greater share of the attention of philosophers than has hitherto been devoted to them. The bird figured on the accompanying Plate serves well to illustrate the foregoing passage, for up to the present time it is only known to inhabit the extinct volcano of Puracé, where it was discovered by the late M. De Lattre during his travels in the little-trodden countries of New Grenada.

The Eriocnemis Derbianus is a species which differs very remarkably from every other member of the genus, both in the coal-black colouring of its feathered legs and in the brilliant metallic golden green of its upper and under tail-coverts. No other traveller but De Lattre has, I believe, obtained examples of this bird; by him, however, at least forty of both sexes were procured, all of which realized very high prices. These examples were so precisely alike both in colour and markings that they scarcely presented a shade of difference.

In the year 1846, MM. De Lattre and Bourcier named this species in honour of the late Earl of Derby, as a just tribute of respect to that distinguished nobleman, whose life was certainly not rendered less happy by his study of the branch of natural science to which he was so much attached.

The male has a wash of green on the forehead; the head, all the upper surface and wing-coverts of a golden bronzy hue; all the under surface shining golden green; wings purplish brown; upper and under tail-coverts brilliant metallic green; tail, feathers of the tarsi, and bill black.

The female has a wash of green on the forehead; all the upper surface golden bronze; under surface similar in hue, but lighter and more brilliant; upper and under tail-coverts metallic golden green; wings purplish brown; tail black; feathers of the tarsi black towards the knee and greyish white near the feet.

The Plate represents two males and a female of the size of life on the Maxillaria leptosepala. 


\section{$2 \mathrm{BHL}$ Biodiversity Heritage Library}

Gould, John. 1860. "Eriocnemis derbianus, Derby's Puff-leg. [PI. 279]." A monograph of the Trochilidae, or family of humming-birds 4, https://doi.org/10.5962/p.317088.

View This Item Online: https://www.biodiversitylibrary.org/item/108334

DOI: https://doi.org/10.5962/p.317088

Permalink: https://www.biodiversitylibrary.org/partpdf/317088

\section{Holding Institution}

Smithsonian Libraries

\section{Sponsored by}

Smithsonian Institution Libraries

\section{Copyright \& Reuse}

Copyright Status: NOT_IN_COPYRIGHT

This document was created from content at the Biodiversity Heritage Library, the world's largest open access digital library for biodiversity literature and archives. Visit BHL at https://www.biodiversitylibrary.org. 